\title{
THE ANALYSIS OF ILLOCUTIONARY ACTS USED BY SHERLY ANNAVITA IN INDONESIA LAWYERS CLUB
}

\author{
${ }^{1}$ Lukluatul Maulidiyah, ${ }^{1,2}$ Didin Nuruddin Hidayat, ${ }^{1}$ Alek, \& ${ }^{\mathbf{1}}$ Maya Defianty \\ ${ }^{1}$ English Lecturer, Faculty of Educational Sciences, UIN Syarif Hidayatullah Jakarta, \\ Indonesia \\ ${ }^{2}$ Corresponding Author Email: didin.nuruddin@uinjkt.ac.id
}

\begin{tabular}{|c|c|}
\hline Article Info & Abstract \\
\hline $\begin{array}{l}\text { Article History } \\
\text { Received: October } 2020 \\
\text { Revised: December } 2020 \\
\text { Published: January } 2021\end{array}$ & $\begin{array}{l}\text { Understanding the illocutionary speech acts performed by prominent speakers in } \\
\text { a formal event may bring significant impacts to provide an in-depth explanation } \\
\text { of the purposes that the speakers intend to deliver. Sherly Annavita, a young } \\
\text { politician and social influencer, was invited to one of Indonesia's prominent TV }\end{array}$ \\
\hline $\begin{array}{l}\text { Keywords } \\
\text { Writing instructions; } \\
\text { ELT learning; } \\
\text { Communicative learning; }\end{array}$ & $\begin{array}{l}\text { shows. As an influencer, her statements have often initiated a social movement, } \\
\text { which led the researchers to examine how she delivered her thoughts in the public } \\
\text { sphere. The present study employed a descriptive qualitative approach to } \\
\text { uncovered what illocutionary speech acts performed by the above-mentioned } \\
\text { politician and the purpose in each speech act. Data analysis of this study found } \\
\text { sixteen (16) illocutionary speech acts performed by Sherly. Assertive } \\
\text { Illocutionary Speech Act dominated her statements, followed by Expressive and } \\
\text { Directive Illocutionary Speech Acts, respectively. Further, of all speech acts } \\
\text { performed, Sherly delivered seven purposes of her statement, namelyexpressing } \\
\text { opinions, notifying, stating arguments, advising, thanking, praising, and } \\
\text { criticizing. }\end{array}$ \\
\hline
\end{tabular}

How to cite: Maulidiyah, L., Hidayat, D. N., Alek, A., \& Defianty, M. (2021). The Analysis of Illocutionary Acts Used by Sherly Annavita in Indonesia Lawyers Club, JOLLT Journal of Languages and Language Teaching, 9(1), 53-60. DOI: https://doi.org/10.33394/jollt.v\%vi\%i.3280

\section{INTRODUCTION}

In communication, speakers do not only produce utterances but also carry out actions by the utterances. They are doing issues with their utterances as soon as they speak due to the language used to hold out an action meant to perform and affect the listeners. Yule (2014) asserted that these actions are likely to be carried out through utterances, often called speech acts. The sentences of speech acts in certain conditions can decide the technique of the sentences. A speaker who needs to convey the meaning or objective of a sentence to their listener should apply it inside the type of speech acts. A variety of factors determines the act of speaking to be chosen. In conveying an intention in speech acts, it is very important to assume in regards to the varied possibilities of utilizing speech acts primarily based on the speaker's place, the speech situation, and the attainable construction throughout the language. Speech acts are carried out by people when communicating a message positively to be conveyed from speakers to listeners. Speech acts focused on the "illocutionary force that entails the perform of creativeness, manipulation, creation, dynamic, and heuristics. Speech acts will also be a part of sociolinguistics, corresponding to dialect or language variation in the speakers' social-cultural context. A speech act idea clarifies that whereas talking a speaker is doing issues as effectively, for situations: apology, thanks, asking, complain, denial (Zayed, 2014).

Austin (1962, as cited in Mukhroji et al., 2019) stated that if speech acts are used to tell one thing, it is named locutionary act. If it requires the listener to do one thing is called the illocutionary act, and if it affects the listener or requires a response or certain effects from the listener is a perlocutionary act. Roberts (2018) proposed that one of the speech acts above could 
be present in human communication in everyday life. For instance, the government provides orders to its citizens to do certain things, or parents forbid their children to do something. The two examples above are very intently associated with speech acts. Furthermore, in communication, generally, speakers' utterances do not only have one meaning, but there are particular objectives that the speaker intends to achieve.

Austin (1962, as cited in Mukhroji et al., 2019)) further claimed that the aim of an utterance that requires a companion to take action is named the illocutionary act. The intentions conveyed by speakers might be prohibiting, apologizing, thanking, advising, expressing, agreeing, warning, agreeing, rejecting, promising, betting, proposing, permitting and others. Illocutionary speech acts are recognized as speech acts that operate to tell one thing and do one thing and comprise intentions and utterances. Illocutionary act should not simply be recognized as a result of who the speaker is, to whom, when and the place of the speech act is performed. This illocutionary action is an important part of| understanding speech acts. Illocutionary actions are often called the act of doing something. Moreover, Searle (1969), cited in Mufiah \& Rahman, 2018), categorized the illocutionary speech acts into five kinds of speech: representatives, directives, commissive, expressive, and declarative.

Besides, the speech idea was one in all disciplines data devoted as a technique of analyzing discourse studies. Concerning this, the researchers are interested to investigate Illocutionary act. Illocutionary act is an utterance with some function of the mind. Any person would possibly make a statement, an offer, and an explanation or for another communicative purpose. Moreover, language can even be essential among many politicians and millennial influencers. In the world of politics, speech acts are used as a device to seek political assistance. Concerning this, it is clear that uttering the speech act could be politicians and millennial influencers' political actions, which can be made a potential way of channeling up through language.

One of the popular politicians and likewise as a millennial influencer is Sherly Annavita. She is popularly recognized throughout social media, confirmed by a significant number of followers in her Instagram and Twitter accounts. Most of her posts on social media are associated with political aspects. Furthermore, she can also be a motivator that is all times concerned in some motivation programs in many areas. Besides, she obtained an award in 2013 as the second winner of "I am President" that the topic is regarding Indonesia's issues in 2030.

A TV program called Indonesia Lawyer's Club (ILC) was discussing a topic about "Perlukah Indonesia Dipindahkan?" There have been many illocutionary speech acts or having completely different intentions utilized by some politicians of their statements. However, in this research, the researchers only focus on Sherly Annavita's statements. As a result of this fact, speech acts on this program are essential to study so that contained throughout the speech could be understood as a complete message to be conveyed might be transferred correctly.

Aribowo (2013) found four types of illocutionary acts proposed by Searle (1969): representative/assertive, directive, expressive and commissive. The representative/assertive was mostly found. Nurhayati and Yuwartatik (2016) studied illocutionary and perlocutionary, acts on main characters dialogues in John Milne's novel: The Black Cat. The study revealed that the dialogue possessed five types of illocutionary acts proposed by Searle (1969): declarative, assertive, expressive, directives, commissives. The most dominant ones were assertive and expressive. Another research conducted by Dzumillah (2016) studied the illocutionary and perlocutionary act, and the result of her study showed that all types of illocutionary acts proposed by Searle (1969) were found in this movie, with representative as the most frequently used type of illocutionary act.

This research focused on one kind of speech acts in Indonesia Lawyers Club as one of the discussion programs on TV ONE channel, which is available to watch on the Youtube channel. Based on the background above, the researcher focused on identifying, analyzing, and 
describing the type of speech acts utilized by Sherly Annavita, as one of the speakers in the ILC program, talking about the issue of "Perlukah Indonesia Dipindahkan?" This research aims to describe the type of illocutionary acts present in Sherly Annavita's statements by following Austin (1962) and Searle (1969) categorization of speech acts. They include assertive, commissive, directives, expressive, and declarative. Another purpose is to describe the reason why Sherly Annavita performs illocutionary acts. To fulfill this aim, the researchers deeply analyze the words, phrases, and sentences by considering the context of the situation. By doing so, the speaker's intentions in delivering the statements are anticipated to be explored.

\section{RESEARCH METHOD}

This research focused on the speech acts performed by Sherly Annavita in Indonesia Lawyers Club (ILC) show. This study employed a descriptive qualitative approach, which intends to understand a research subject's phenomena by describing it through the type of words or writing (Moleong, 2010). The descriptive technique is used to describe, clarify and analyze the phenomenon which occurred behind the data. Sutopo (2002) asserted that the descriptive method's data analysis is finished naturally objective and factual. It implies that the researcher applies a set of procedures used for problem-solving based on the factual data.

This study's subject was Sherly's language, while the object of this study was her speech acts focusing on the illocutionary speech acts. Data collection techniques involved listening, reading, and simultaneous notetaking to the video source. This technique of collecting data is non-interactive because it does not involve the researchers interacting with the subjects being studied. The procedures of data collection were illustrated as follows: (a) downloaded the video associated with the topic; (b) watched the video source; (c) made the datasheet to categorise the data primarily based on the categorization and coded them; (d) selected the data from the statements following the objective of the study, and; (e) classified the data to be tabulated into the datasheet.

The strategy in analyzing the data on this study employed the additional lingual equivalent methodology, which analyzed further lingual components, such as connecting language issues with issues outside the discourse (Mahsun, 2013). All the issues that might be relevant with the speech acts such as referring to meaning, information and context of the speech will also take part in the analysis. This study examined the relationship between types, meaning, and influence. The data analysis technique in this study employed descriptive techniques. In this case, the researchers described the speech act in the ILC program on the topic of "Perlukah Indonesia Dipindahkan?" that consists of: (a) identification of data, this step applies to search out speech acts; (b) data classification, making speech groupings into three types of speech acts; (c) applying the theories associated with the issue and something needed primarily based on the aim of the study. In this case, the researchers use the speech act theory to identify the three kinds of speech act, and; (d) make a conclusion primarily based on the analyzed data.

\section{RESEARCH FINDINGS AND DISCUSSION}

The data were analyzed by classification made by Searle (1969, as cited in Leech, 1983) concerning illocutionary acts are primarily based on varied criteria.

\section{Assertive}

This illocutionary is certain to the reality of the proposition expressed, for instance, states, proposes, brags, complains, expresses opinions, experiences, notifies, suggests, boasts, complains, demands, reports.

Sample 1. Assertive (expressing opinion)

"Jadi ketika sekarang, beliau menjadikan alasan pindahnya ibukota ini karena macet, banjir, polusi dll maka seolah sekarang beliau sedang mengonfirmasi kegagalannya dalam memenuhi janji kampanye beliau sebagai seorang president." 
(So, when he makes excuses to move because of traffic, floods, pollution, etc. So now he is confirming his failure to fulfill his campaign promise as president.)

Sample 2. Assertive (expressing opinion)

"Dan jika alasanya tentang pemerataan pembangunan, maka saya fikir tentu saja solusi yang seharusnya ditawarkan adalah meningkatkan pengawasan pemerataan itu ke daera-daerah, bukan memindahkan ibukota tersebut."

(And if the reason is for equitable development, then I think, of course, the solution that should be offered is to increase the supervision of equity in the regions, not move the capital).

Sample 3. Assertive (expressing opinion)

"Sehingga dengan semua argument tadi saya fikir mengambil kesimpulan untuk memindahkan ibukota ke wilayah lain, membangun ibukota baru, rasanya itu belum perlu, solusinya adalah, tetap kembali pada azaz efektivitas, efesiensi, menciptakan lapangan kerja, menghapus KKN, memberantas KKN sampai ke akar-akarnya, dan yang paling penting adalah kembali tegakkan undang2 dasar pasal 33 itu, dengan murni dan konsekuen."

(So with all the arguments, I think I concluded to move the capital to another region, to build a new capital. It seems that it is not necessary. The solution is, keep returning to the principle of effectiveness, efficiency, creating jobs, erasing KKN (corruption, collusion, and nepotism), eradicating KKN to its roots, and the most important thing is to re-enforce the Article 33 Constitutional Law, purely and consistently).

Sample 4. Assertive (expressing opinion)

"Seandainya alasannya adalh pemerataan pembangunan maka saya fikir seharusnya lebih bermanfaat warga Aceh atau warga Papua yang merasakan pemindahan ibukota tersebut."

(If the reason is the equitable development, I think it should be more useful for Acehnese or Papuans who feel the removal of the capital).

Sample 5. Assertive (notifying)

"Namun alasan utama presiden yang tadi kami saksikan bersama di awal program ini. Setidaknya ada 4 yang ingin saya highlight. Berikut alasannya: Banjir, Macet, Polusi, Perataan tanah."

(But the main reason for the president that we witnessed together at the beginning of this program. At least, there are 4 that I want to highlight. Here are the reasons: Flooding, Traffic jam, Pollution, Ground leveling).

Sample 6. Assertive (notifying)

"Dana 466 triliun itu bukan dana yang kecil. Kalau berdasarkan kami milenial membaca, sumber-sumbernya kurang lebih dari jual asset, kemudian hutang lagi, dan itu adalah membutuhkan dana yang sangat besar dan sangat banyak."

(The 466 trillion rupiahs is not a small fund. If based on our millennial reading, the sources are less than selling assets, then debt again, and that is a very large and very large amount of funds needed).

Sample 7. Assertive (notifying)

"Kondisi Negara sedang tidak baik2 saja. Kita tahu bahwa dalam tahun 2019 ini diperkirakan hutang Indonesia mencapai 275 triliun, itu baru hutang bunganya saja, belum pokoknya, dan ini $2 x$ lipat bunganya dibandingkan tahun akhir pemerintahan Pak SBY."

(The country's condition is not good. We know that in 2019 Indonesia's debt was estimated to reach 275 trillion. That is just the interest debt, not even the debt, and this is double the interest compared to the last year of Pak SBY's government).

Sample 8. Assertive (expressing opinion) 
"Saya kira anak muda, tidak begitu peduli siapa presidennya, siapa saja yang memimpin silahkan, namun anak muda itu yang pasti akan peduli dengan bagaimana kinerjanya, bagaimana dampaknya kepada kami."

(I think young people do not really care who the president is, whoever leads it, but the young people will certainly care about how it is performing, how it will affect us).

Sample 9. Assertive (stating argument)

"Maka ini bisa dibilang adalah sebuah alasan yang klise, tidak menjawab masalah, tidak menjawab permasalahan, bahkan terkesan pembelaan belaka."

(Then this is arguably a cliché reason, not answering the problem, not answering the problem, even seeming to be a mere defense).

\section{Directive}

This illocutionary aims to provide an impact on the type of actions taken by speakers. This illocutionary, for instance, orders, orders, requests, demands, advises.

Sample 1. Directive (advising)

"jadi jangan sampai alasan pemerataan pembangunan tersebut justru memicu konflik baru, seperti halnya kecemburuan social bagi provinsi-provinsi lainnya."

(so do not let the reasons for even distribution of development trigger new conflicts, such as social jealousy for other provinces).

Sample 2. Directive (advising)

"Sehingga jangan sampai pemindahan ibu kota ini mengenyampingkan sesuatu yang seharusnya diutamakan dan diprioritaskan."

(So, do not let the movement of this capital city put aside something that should be prioritized and prioritized).

Sample 3. Directive (advising)

"Bahkan seharusnya Negara hadir untuk memastikan terlaksananya hal tersebut demi keadilan dan kemakmuran rakyat Indonesia."

(Even the State should be present to ensure the implementation of this matter for the sake of justice and prosperity of Indonesia's people).

\section{Expressive}

This illocutionary is to precise or express the speaker's psychological perspective to the situation implied in illocutionary, for instance, to say thanks, congratulate, apologize, criticize, praise, express condolences, and so forth.

\section{Sample 1. Expressive (thanking)}

"Bang Karni yang saya hormati, para senior dan hadirin sekalian, selamat malam saya ucapkan, terimakasih saya ucapkan karena sudah diberi kesempatan untuk sedikit memberikan opini. Boleh dong, millennial ikut memberikan pendapat dan pandangannya."

(Dear Sir, I respect all the seniors and attendees, good evening I say, thank you for saying that I was allowed to give opinion. It's possible. Millennials share their opinions and views).

Sample 2. Expressive (praising)

"Pak Jokowi kepada kami saya kira baik2 saja, dia ramah senyum, kita bisa liat beliau keluarganya rukun, beliau juga ramah."

(Mr. Jokowi to us, I think it's fine, he is smiling, we can see he is a harmonious family, he is also friendly).

Sample 3. Expressive (criticizing)

"Yang rata2 bermasalah itu kan sbenarnya adalah tataran kebijakannya." 
(The actual problem is the level of policy).

Sample 4. Expressive (criticizing)

"Alasan ini sebenarnya sedikit besarnya menohok kapasitas pak jokowi sendiri dalam memerintah. Karena bukankah salah satu program besar pak jokowi saat itu mencalonkan diri sebagai gubenur."

(This reason is actually a bit large to meet the capacity of Pak Jokowi himself to govern. Because was not one of the big programs that Pak Jokowi was nominating himself as governor.)

The expressions in the findings above included an assertive illocutionary speech act expressing opinions, notifying information, and stating something. Roberts (2018) claimed that it is common to find these expressions in a speech. This can be shown in samples 1 to 4 indicating that the expressions were intended to express the opinions to the public. Sample 1 informs that Jokowi, at this time as if he confirms his failure in keeping his promises in the campaign if he makes the removal of the capital as the reason for the traffic jam. Sample 2 tells about if it is indeed equitable development as a reason for moving the capital. As a millennial representative of influencers, Sherly thinks, of course, the solution that should be offered is to increase supervision of equity to the regions, not to move the capital. Sample 3 tells us that building a new capital does not seem necessary. The solution is to keep returning to the principles of effectiveness, efficiency, create jobs, erase $\mathrm{KKN}$, eradicate $\mathrm{KKN}$ to its roots, and most importantly, re-enforce the basic rules of Article 33, purely and consistently. While sample 4 tells that if the reason is equitable development, we believe it should be more useful for Acehnese or Papuan residents who feel the relocation of the capital. Next, sample 5 to 7 expressions are expressions of government funds notifications that are known at this time, while sample 8 to 9 expressions are stating that millennials do not care who the president is. Nevertheless, the young man is certain that millennials will care about how the president is performing and how he or she impacts the nation.

Besides assertive, the speech also included directive speech acts that include advice. The expressions sample 1 to 3 show that the advice is from millennial influencers' representatives to Mr Jokowi and his government. There is no reason for even distribution of development as an excuse to relocate the new capital instead of triggering new conflicts such as social jealousy for other provinces. Also, do not let the removal of this capital even set aside something that should be prioritized and prioritized. Furthermore, the State should be present to ensure the implementation of this matter.

Lastly, the speech also included expressive illocutionary speech acts that said thanks, praising, and criticizing. A fairly similar result is found on Dzumillah's study (2016)Sample 1 shows that Sherly thanks the audience for giving them the chance to speak up in front of the public. Sample 2 shows that Sherly gives praise to Jokowi that Mr Jokowi is a person who smiles, is friendly, and gets along well with his family. While sample 3 shows that Sherly criticized that the average problem with Pak Jokowi is at the policy level. Sample 4 shows that the reason that was used as an excuse in moving the capital was striking Pak Jokowi's capacity to govern Indonesia.

The researchers found 9 assertive speech acts, which are mostly used in ILC show because assertive has a function to notify and give the speaker an opinion. Second, the type of illocutionary act used by Sherly in the ILC group is directive. Directive is the second place of Illocutionary acts appears in ILC used by Sherly Annavita. The researcher found that directive acts have the function of advising the speaker. Expressives are the other type of Illocutionary Acts. They were not used as many as assertive (Sameer, 2017). The expressive found was only in four statements. 
After analyzing all the data, this research is enough to answer the formulation of the problems. The formulation of the problem is, "what are the types of illocutionary acts used by Sherly in ILC and the reason why Sherly Annavita performs the illocutionary acts. Through the data analysis, the researchers found that Sherly's statements were grouped into the illocutionary acts of three types: assertive, directive, and expressive. The most dominant type is assertive.

\section{CONCLUSION}

This study has uncovered some findings: a) Sherly Annavita performed some illocutionary speech acts, namely nine (9) assertive illocutionary speech acts, three (3) directive illocutionary acts, and four (4) expressive illocutionary speech act. Moreover, this study also revealed six (6) purposes of illocutionary speech performed by Sherly Annavita, namely giving information, giving opinions, apologising, praising, and criticizing.

This study has also presented theoretical and practical significance. Theoretically, the research results enrich the theories regarding the analysis of political language utilized by Sherly Annavita as a millennial influencer in her statements in ILC on the topic "Perlukah Indonesia Dipindahkan?" Practically, this research can provide the following significance: a) The findings of the research help understand how a language is used to hold certain actions, why certain actions should be carried out, and how it impacts the hearers considered from the analysis of speech acts; b) This study will also be useful for the linguistic lecturers and language learners since this study provides an example and analysis of illocutionary acts, and; c) Future researchers could consider this study for their theoretical basis useful to investigate the data and speech acts in a completely different context.

\section{REFERENCES}

Aribowo, S. Y. (2013). The illocutionary acts of written conversations in the tenth-grade senior high school students' textbook: Look Ahead I. Universitas Negeri Yogyakarta.

Austin, J. L. (1962). How to do things with words. Oxford University Press.

Dzumillah, A. (2016). The illocutionary and perlocutionary act in The Reasonable Doubt, a movie directed by Peter Howitt. UIN Syarif Hidayatullah Jakarta.

Leech, G. N. (1983). Principle of Pragmatics. Longman.

Mahsun, M. S. (2013). Metode penelitian bahasa: Tahapan, strategi, metode, dan tekniknya. Rajagrafindo Persada.

Moleong, L. J. (2010). Metodologi penelitian kualitatif. Remaja Rosda Karya.

Mufiah, N. S., \& Rahman, M. Y. N. (2018). Speech Acts Analysis of Donald Trump's speech. PROJECT: Professional Journal of English Education, 1(2), 125-132.

Mukhroji, M., Nurkamto, J., Subroto, H. D. E., \& Tarjana, S. S. (2019). Pragmatic forces in the Speech Acts of EFL speakers at Kampung Inggris, Indonesia. Journal of Social Studies Education Research (JSSER), 10(1), 38-60.

Nurhayati, A. D., \& Yuwartatik, Y. (2016). Illocutionary and perlocutionary acts on main characters dialogues in John Milne's novel: The Black Cat. Indonesian Journal of Language Teaching and Linguistics (IJOLTL), 1(1), 67-96.

Roberts, C. (2018). Speech Acts in discourse context. In D. Fogal, M. Moss, \& D. Harris (Eds.), New Work on Speech Acts. Oxford University Press.

Sameer, I. (2017). The analysis of speech acts patterns in two Egyptian inaugural speeches. 
Studies in English Language and Education, 4(2), 134-147.

Searle, J. R. (1969). Speech acts: An essay in the philosophy of language. Cambridge University Press.

Sutopo, H. B. (2002). Pengantar penelitian kualitatif. Universitas Sebelas Maret.

Yule, G. (2014). The study of language (5th ed.). Cambridge University Press.

Zayed, N. M. (2014). Jordanian EFL Teachers and Students Practice of Speech Acts in the Classroom. International Journal on Studies in English Language and Literature (IJSELL), 2(5), 1-10. 